\title{
A patient with four metachronous cancers and multiple adenomatous colon polyps harboring the American Founder Lynch syndrome mutation: a case report
}

\author{
Lindsay Dohany*, Whitney Ducaine, Dana Zakalik \\ From 14th Annual Meeting of the Collaborative Group of the Americas on Inherited Colorectal Cancer \\ Dallas, TX, USA. 12-13 October 2010
}

\section{Background}

Lynch syndrome (LS) is a genetic disorder that accounts for approximately $3 \%$ of all colorectal cancers (CRC) [1]. Clinical characteristics of LS include proximal CRC, multiple CRCs, occurrence at a young age, accelerated carcinogenesis, and an increase in risk of extracolonic cancers [1]. LS is an autosomal dominant disorder, caused by germline mutations in DNA mismatch repair (MMR) genes. Mutations in $\mathrm{MSH} 2$ account for $1-2 \%$ of all CRCs and up to $20 \%$ of these are large germline deletions [2]. The MSH2 deletion of exons 1-6 has been characterized as a North American Founder Mutation (AFM) $[2,3]$.

\section{Case report}

A 68-year-old Caucasian male presented to cancer genetics following a second primary diagnosis of infiltrating poorly differentiated adenocarcinoma of the colon. His history included; moderately differentiated invasive adenocarcinoma of the sigmoid colon at age 40; left ureteral carcinoma diagnosed at 54; and a bladder carcinoma diagnosed at age 59. Additionally, colonoscopy revealed multiple adenomatous polyps within a ten year period. Family history is significant for a son diagnosed with colon cancer at age 34, father with gastric cancer, two paternal aunts and paternal grandfather with colon cancer, and German ancestry. Peripheral blood was sent for analysis of the MLH1 and $M S H 2$ genes [4]. Molecular analysis identified a deleterious

\footnotetext{
* Correspondence: Lindsay.dohany@beaumonthsopitals.com Cancer Genetics Program, William Beaumont Hospital, Royal Oak, Michigan, USA
}

mutation, del exons 1-6, in the $M S H 2$ gene. This results in the premature truncation of the MSH2 protein and confirms the diagnosis of LS.

\section{Conclusions}

This case reveals a LS patient with a history of four metachronous cancers. Phenotypic variations exist amongst the different MMR genes causative for LS [5-7]. Individuals with $M S H 2$ mutations are at a higher risk of developing extracolonic cancers than individuals with MLH1 mutations [5,6]. There is a 7 -fold higher risk for urinary tract cancers in individuals with $\mathrm{MSH} 2$ mutations and male carriers have up to a $28 \%$ lifetime risk of developing uroepithelial cancers [8]. It is controversial whether or not large deletions lead to a more severe phenotype with multiple cancers and earlier ages of onset $[7,9]$. The severity of clinical presentation may correlate more with which MMR gene is altered than the specific mutation type [9]. A better understanding of genotype-phenotype correlations may allow for a personalized surveillance plan in the future.

\section{Published: 10 March 2011}

\section{References}

1. Lynch HT, et al: Review of the Lynch syndrome: history, molecular genetics, screening, differential diagnosis, and medicolegal ramifications. Clinical Genetics 2009, 76:1-18.

2. Clendenning $\mathrm{M}$, et al: Origins and Prevalence of the American Founder Mutation of MSH2. Cancer Research 2008, 68(7):2145-2153.

3. Wagner A, et al: Molecular Analysis of Hereditary Nonpolyposis Colorectal Cancer in the United States: High Mutation Detection Rate among Clinically Selected Families and Characterization of an American Founder Genomic Deletion of the MSH2 Gene. American Journal of Human Genetics 2003, 72:1088-1100.

\section{Biomed Central}


4. Colaris $^{\circledR}$ Technical Specifications, Myriad Genetic Laboratories: 2009 [http://www.myriad.com]

5. Vasen HFA, et al: MSH2 Mutation Carriers Are at Higher Risk of Cancer Than MLH1 Mutation Carriers: A Study of Hereditary Nonpolyposis Colrectal Cancer Families. Journal of Clinical Oncology 2001, 19(20):4074-4080.

6. Lin $\mathrm{KM}$, et al: Colorectal and extracolonic cancer variations in MLH1/MSH2 hereditary nonpolyposis colorectal cancer kindreds and the general population. Diseases of the Colon and Rectum 1998, 41(4):428-433.

7. Kastrinos Fay, et al: Phenotype Comparison of MLH1 and MSH2 Mutation Carriers in a Cohort of 1,914 Individuals Undergoing Clinical Genetic Testing in the United States. Cancer Epidemiol Biomarkers Prev 2008, 17(8):2044-2051.

8. Watson $\mathrm{P}$, et al: The Risk of Extra-colonic, Extra-endometrial Cancer in the Lynch Syndrome. International Journal of Cancer 2008, 123(2):444-449.

9. Bandhuin LM, et al: Characterization of $\mathrm{hMLH} 1$ and $\mathrm{hMLH} 2$ gene dosage alterations in Lynch Syndrome patients. Gastroenterology 2005, 129:846-854.

doi:10.1186/1897-4287-9-S1-P8

Cite this article as: Dohany et al.: A patient with four metachronous cancers and multiple adenomatous colon polyps harboring the American Founder Lynch syndrome mutation: a case report. Hereditary Cancer in Clinical Practice 2011 9(Suppl 1):P8.

\section{Submit your next manuscript to BioMed Central} and take full advantage of:

- Convenient online submission

- Thorough peer review

- No space constraints or color figure charges

- Immediate publication on acceptance

- Inclusion in PubMed, CAS, Scopus and Google Scholar

- Research which is freely available for redistribution

Submit your manuscript at www.biomedcentral.com/submit 